\title{
Combined Approach to Stroke Thrombectomy Using a Novel Short Flexible Aspiration Catheter with a Stent Retriever
}

\section{Preliminary Clinical Experience}

\author{
Sebastian Remollo ${ }^{1}$ (D) Mikel Terceño ${ }^{1,2} \cdot$ Mariano Werner $^{1} \cdot$ Carlos Castaño $^{1}$ María Hernández-Pérez ${ }^{3} \cdot$ \\ Jordi Blasco ${ }^{4}$ Luis San Román ${ }^{4}$ Pepus Daunis-i-Estadella ${ }^{5}$ Santiago Thió-Henestrosa ${ }^{5}$. Víctor Cuba ${ }^{6}$ \\ Alfredo Gimeno7 · Josep Puig ${ }^{8}$
}

Received: 7 April 2021 / Accepted: 11 May 2021 / Published online: 20 July 2021

(c) The Author(s) 2021

\begin{abstract}
Background Large-bore aspiration catheters enabling greater flow rates and suction force for mechanical thrombectomy might improve outcomes in patients with stroke secondary to large-vessel occlusion. Complete or near-complete reperfusion after a single thrombectomy pass (first-pass effect) is associated with improved clinical outcomes. We assessed the efficacy and safety of novel MIVI Q ${ }^{\mathrm{TM}}$ aspiration catheters in combination with stent-retriever devices.

Methods We retrospectively analyzed demographics, procedure characteristics, and clinical data from consecutive patients with acute anterior large-vessel occlusion treated with a combined approach using MIVI $\mathrm{Q}^{\mathrm{TM}}$ aspiration catheters and stent retrievers. Reperfusion was defined according to the modified thrombolysis in cerebral infarction (mTICI) score. Clinical outcomes were measured by the National Institute of Health Stroke Scale (NIHSS) and modified Rankin scale (mRS) scores.

Results We included 52 patients (median age, 75 y IQR: 64-83); 31 (59.6\%) women; 14 (26.9\%) with terminal internal carotid artery occlusions, 26 (50\%) middle cerebral artery (MCA) segment M1 occlusions, and $12(23.1 \%)$ MCA segment M2 occlusions; median NIHSS score at admission was 19 (IQR: 13-22). After the first pass, 25 (48\%) patients had $m$ TICI $\geq 2 c$. At the end of the procedure, $47(90.4 \%)$ had $\mathrm{mTICI} \geq 2 \mathrm{~b}$ and $35(67.3 \%)$ had $\mathrm{mTICI} \geq 2 \mathrm{c}$. No serious device-related adverse events were observed. Symptomatic intracranial hemorrhage developed in 1 patient. Mean NIHSS score was 13 at $24 \mathrm{~h}$ and 5 at discharge. At 90 days, 24 (46.2\%) patients were functionally independent (mRS 0-2).

Conclusion This preliminary study found good efficacy and safety for MIVI Q Q ${ }^{\mathrm{TM}}$ aspiration catheters used in combination with stent-retriever devices.
\end{abstract}

Keywords Brain ischemia $\cdot$ Stroke $\cdot$ Mechanical thrombectomy $\cdot$ Device $\cdot$ Combined approach thrombectomy

Availability of Data and Material (data transparency) Data are available from the corresponding author upon reasonable request.

Sebastian Remollo

sremollo@gmail.com

1 Department of Neurosciences, Hospital Universitari Germans Trias i Pujol, Interventional Neuroradiology Unit, Carretera del Canyet, s/n, 08946 Badalona, Spain

2 Stroke Unit, Hospital Universitari Dr. Josep Trueta, Girona, Spain

3 Stroke Unit, Department of Neurosciences, Hospital Universitari Germans Trias i Pujol, Badalona, Spain
4 Neurointerventional Department C.D.I, Hospital Clinic of Barcelona, Barcelona, Spain

5 Department of Computer Science, Applied Mathematics and Statistics, University of Girona, Girona, Spain

6 Interventional Neuroradiology, Hospital Universitari de Bellvitge, L'Hospitalet de Llobregat, Spain

7 Radiology Department, University Hospital of Vall d'Hebron, Barcelona, Spain

8 IDI-Radiology, University Hospital Dr Josep Trueta, Girona, Spain 


$\begin{array}{ll}\text { Abbreviations } \\ \text { ASPECTS } & \text { Alberta stroke program early CT score } \\ \text { CAPTIVE } & \text { Continuous aspiration prior to intracranial vas- } \\ & \text { cular embolectomy } \\ \text { CT } & \text { Computed tomography } \\ \text { FPE } & \text { First-pass effect } \\ \text { ICH } & \text { Intracranial hemorrhage } \\ \text { IQR } & \text { Interquartile range } \\ \text { LTSW } & \text { Last time seen well } \\ \text { LVO } & \text { Large-vessel occlusion } \\ \text { MCA } & \text { Middle cerebral artery } \\ \text { MRS } & \text { Modified Rankin scale } \\ \text { MTICI } & \text { Modified thrombolysis in cerebral infarction } \\ & \text { scale } \\ \text { NIHSS } & \text { National Institutes of Health Stroke Scale } \\ \text { PCA } & \text { Primary combined approach } \\ \text { SAVE } & \text { Stent-retriever assisted vacuum-locked extrac- } \\ & \text { tion } \\ \text { SICH } & \text { Symptomatic intracranial hemorrhage } \\ \text { TFPE } & \text { True first-pass effect } \\ \text { TIA } & \text { Transient ischemic attack } \\ \text { TPA } & \text { Tissue plasminogen activator }\end{array}$

\section{Introduction}

Randomized clinical trials have demonstrated the efficacy of mechanical thrombectomy for acute ischemic stroke secondary to large-vessel occlusion [1-5]. Mechanical thrombectomy aims to achieve complete reperfusion, ideally after a single pass of the thrombectomy device through the occluded segment (termed the first-pass effect, FPE) $[6$, 7]. The FPE is an independent predictor of good clinical outcome [8], and the first-pass rate is a metric of technical success. Modern mechanical thrombectomy devices are associated with higher reperfusion rates, shorter procedure times, better clinical outcomes, and lower risk of mortality [8]; however, although the physical properties influencing the effectiveness of different large-bore aspiration catheters have been investigated [9], the superiority of any specific device over another has yet to be demonstrated in clinical trials [10].

The MIVI Q ${ }^{\mathrm{TM}}$ (MIVI Neuroscience, Eden Prairie, MN, USA) is a novel CE-approved device designed to provide greater suction and flow [11]. We assessed the technical efficacy and safety of this new catheter when used in combination with stent-retriever devices in patients with acute stroke due to anterior circulation large-vessel occlusion.

\section{Methods}

\section{Patients}

We retrospectively studied consecutive patients with acute ischemic stroke due to large-vessel occlusion in the anterior circulation (terminal internal carotid artery or middle cerebral artery (MCA) segments M1 or M2, excluding those with simultaneous cervical carotid and intracranial tandem occlusions) who were treated with MIVI $\mathrm{Q}^{\mathrm{TM}}$ aspiration catheters in combination with stent retrievers as the firstline treatment in a comprehensive stroke center between June 2019 and May 2020. All thrombectomy procedures were performed by 4 interventional neuroradiologists, all of whom had $\geq 4$ years experience in endovascular stroke treatment. The decision to use the MIVI $\mathrm{Q}^{\mathrm{TM}}$ aspiration catheters as well as the type of stent retriever was at the discretion of the operator. Inclusion criteria were age $\geq 18$ years, absence of pregnancy, acute ischemic stroke from large-vessel occlusion confirmed by computed tomography angiography or magnetic resonance angiography, premorbid modified Rankin scale (mRS) score $\leq 2$, clinically significant neurological deficit, defined as assessed National Institutes of Health Stroke Scale (NIHSS) score $\geq 6$ and time from last seen well to treatment $\leq 24 \mathrm{~h}$. Intravenous thrombolysis was administered before mechanical thrombectomy in all eligible patients according to established criteria [12]. The study received institutional review board approval. After mechanical thrombectomy, patients or their representatives provided informed consent for imaging, procedural, analytical, and clinical data to be used in future retrospective studies. Our institution's ethics committee waived the need for further specific informed consent for the current study.

\section{Data Collection}

We prospectively recorded age, sex, comorbidities, NIHSS score at admission and $24 \mathrm{~h}$ after mechanical thrombectomy, Alberta stroke program early CT score (ASPECTS) at admission, site of occlusion, timing of medical and interventional treatments, devices used, reperfusion outcomes, intracranial hemorrhage (ICH) and symptomatic ICH (sICH) [13] on 24-h follow-up imaging, device-related or technique-related adverse events, and modified Rankin scale (mRS) score at day 90.

\section{Outcome Variables}

We recorded puncture-to-revascularization time, divided into puncture-to-first-run time and first-run-to-final-revascularization time. To determine procedural efficacy, an independent experienced interventional neuroradiologist blinded to the interventional team's assessment classified 
technical success after a single pass according to the modified thrombolysis in cerebral infarction (mTICI) scale as FPE (mTICI $\geq 2 \mathrm{c})$ or true FPE (tFPE= mTICI 3$)[14,15]$, as well as final reperfusion scores according to the same criteria.

To determine procedural safety, we analyzed ICH according to the European Cooperative Acute Stroke StudyII definition [13] on computed tomography $24 \mathrm{~h}$ after the procedure, early neurological deterioration ( $\geq 4$ points from baseline NIHSS $24 \mathrm{~h}$ after the procedure), clinical complications deemed procedural by the attending interventionist, and deaths within 30 days attributable to the procedure. Clinical outcomes were assessed by the mRS score at 90 days. Good clinical outcome was defined as $\mathrm{mRS} \leq 2$.

\section{Thrombectomy Technique}

The MIVI $\mathrm{Q}^{\mathrm{TM}}$ is a novel aspiration catheter designed to maximize flow and minimize pressure loss [11]. The proximal three quarters of the catheter shaft have been replaced with a $119 \mathrm{~cm} 0.020^{\prime \prime}$ stainless steel pusher wire. This innovation allows the full internal area of the guiding catheter to provide a higher aspirated flow rate and suction force than standard tubular catheter designs. The outer diameter (OD) of the proximal segments of the $\mathrm{Q}^{\mathrm{TM}}$ is $0.088^{\prime \prime}$; the length of the catheter and the inner diameter (ID) of the distal catheter segments varies according to the model, being $25 \mathrm{~cm}$ and $0.069^{\prime \prime}$ for the Q6, $25 \mathrm{~cm}$ and $0.057^{\prime \prime}$ for the Q5, $30 \mathrm{~cm}$ and $0.043^{\prime \prime}$ for the Q4, and $43 \mathrm{~cm}$ and $0.036^{\prime \prime}$ for the Q3. The aspiration catheter is used with the Super $908 \mathrm{~F}$ guide catheter (MIVI Neuroscience Inc.) (ID 0.090", length $80 \mathrm{~cm}, 90 \mathrm{~cm}$, or $95 \mathrm{~cm}$ ). Pump aspiration is directly applied to the Super 90 guide catheter and the total system length varies as the $\mathrm{Q}^{\mathrm{TM}}$ is extended outward and retracted into the Super 90 guide catheter [11].

Depending on the patient's condition, procedures were done with the patient under local anesthesia, conscious sedation or general anesthesia. Through femoral artery access, the guide catheter was placed in the internal carotid artery of the affected side. A Rebar ${ }^{\mathrm{TM}} 18$ microcatheter (ev3 Inc. Medtronic, Minneapolis, MN, USA) with a Synchro ${ }^{\circledR}$ 0.014" microwire (Boston Scientific for Stryker Neurovascular, Fremont, CA, USA) was advanced through the arterial occlusion. The largest diameter $\mathrm{Q}^{\mathrm{TM}}$ aspiration catheter that would fit in the affected vessel was advanced to the occlusion over the microcatheter and microwire unit in a monorail fashion. Then a stent retriever was advanced through the microcatheter and deployed at the level of the thrombus using the push-and-fluff technique [16]. To increase the cross-sectional area and flow, the microcatheter was removed [17] and pump aspiration was applied to the guiding catheter. The stent retriever was retracted slightly and the $\mathrm{Q}^{\mathrm{TM}}$ was carefully advanced until no flow was present in the aspiration tubing. After 1 min under occlusive aspiration, both devices were slowly retrieved as a unit inside the guiding catheter and then withdrawn while maintaining aspiration (Fig. 1).

\section{Results}

During the 10-month study period, a total of 105 patients with acute ischemic stroke underwent mechanical thrombectomy at Hospital Universitari Germans Trias i
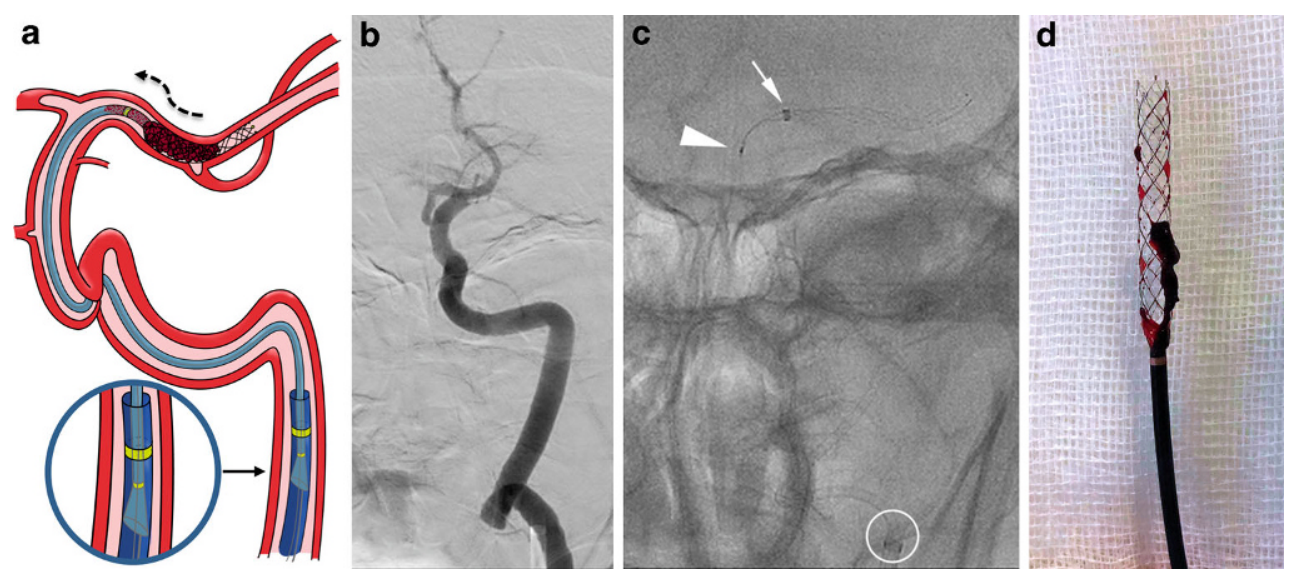

Fig. 1 a Illustration of the $\mathrm{Q}^{\mathrm{TM}}$ and stent retriever combined approach during the thrombus wedging maneuver. After removing the microcatheter, the stent retriever has been slightly retracted and the $\mathrm{Q}^{\mathrm{TM}}$ catheter carefully advanced under pump aspiration to ensure better engagement of the thrombus. The flared proximal tip of the Q catheter (magnified inset) ensures a tight seal between its outer surface and the Super 90 guiding catheter's inner surface, enabling increased suction power (curved black dashed arrow) directly through the guide catheter. b Anteroposterior left internal carotid artery (ICA) angiography through the Super 90 guiding catheter showing a terminal ICA occlusion. c Unsubtracted anteroposterior view showing the combined approach thrombectomy: Distal end of the Super 90 Catheter (white circle), distal end of a Q6 aspiration catheter (white arrow), and a fully deployed Aperio ${ }^{\circledR}$ Hybrid stent with its proximal end inside the Q6 (white arrowhead). d Q6 and Aperio ${ }^{\circledR}$ Hybrid with the "pinned" thrombus 
Table 1 Baseline characteristics of the 52 patients included in the study

\begin{tabular}{|c|c|}
\hline Characteristics & Values \\
\hline Age (years) median (IQR) & $75(64-83)$ \\
\hline Female sex, $n(\%)$ & $31(59.6)$ \\
\hline NIHSS score at admission, median (IQR) & $19(13-22)$ \\
\hline \multicolumn{2}{|l|}{ Pre-stroke $m R S, n(\%)$} \\
\hline 0 & $44(84.6)$ \\
\hline 1 & $4(7.7)$ \\
\hline 2 & $4(7.7)$ \\
\hline \multicolumn{2}{|l|}{ Medical history, $n(\%)$} \\
\hline Hypertension & $34(65.4)$ \\
\hline Diabetes mellitus & $15(28.8)$ \\
\hline Atrial fibrillation & $13(25)$ \\
\hline Dyslipidemia & $28(53.8)$ \\
\hline Smoking & $12(23.1)$ \\
\hline Obesity & $5(9.6)$ \\
\hline Myocardial infarction or coronary artery disease & $13(25)$ \\
\hline Previous stroke or TIA & $8(15.4)$ \\
\hline Anticoagulation & $13(25)$ \\
\hline Antiplatelet & $9(17.3)$ \\
\hline ASPECTS at admission, median (IQR) & $9(8-10)$ \\
\hline \multicolumn{2}{|l|}{ Occlusion site, $n(\%)$} \\
\hline Left side & $30(57.7)$ \\
\hline ICA-T & $14(26.9)$ \\
\hline MCA-M1 & $26(50)$ \\
\hline MCA-M2 & $12(23.1)$ \\
\hline $\begin{array}{l}\text { Time from symptom onset or LTSW to arterial punc- } \\
\text { ture (min), median (IQR) }\end{array}$ & $\begin{array}{l}278 \\
(170-419)\end{array}$ \\
\hline Door-to-groin time (min), median (IQR) & $70(36-96)$ \\
\hline \multicolumn{2}{|l|}{$Q^{T M}$ device used, $n(\%)$} \\
\hline Q3 & $5(9.6)$ \\
\hline Q4 & $7(13.5)$ \\
\hline Q5 & $19(36.5)$ \\
\hline Q6 & $21(40.4)$ \\
\hline \multicolumn{2}{|l|}{ Stent retriever used, $n(\%)$} \\
\hline Aperio Hybrid ${ }^{\circledR}$ & $27(51.9)$ \\
\hline Catch View ${ }^{\circledR}$ & $15(28.8)$ \\
\hline Embotrap II ${ }^{\circledR}$ & $5(9.6)$ \\
\hline $\mathrm{NeVa}^{\circledR}$ & $5(9.6)$ \\
\hline IV tPA administered, $n(\%)$ & $17(32.7)$ \\
\hline
\end{tabular}

$I Q R$ interquartile range, NIHSS National Institute of Health Stroke Scale score, $m R S$ modified Rankin Scale score, TIA transient ischemic attack, ASPECTS Alberta Stroke Program Early CT Score, MCAM1 ICA-T: intracranial carotid T occlusion, M1 segment of the middle cerebral artery, $M C A-M 2 \mathrm{M} 2$ segment of the middle cerebral artery, LTSW last time seen well, $\mathrm{Q}^{\mathrm{TM}}$ (MIVI Neuroscience, Inc., Eden Prairie, MN, USA), Aperio Hybrid ${ }^{\circledR}$ (Acandis company, Pforzheim, Germany), Catch View ${ }^{\circledR}$ (Balt, Montmorency, France), Embotrap II ${ }^{\circledR}$ (Cerenovus, Galway, Ireland), $\mathrm{NeVa}^{\circledR}$ (Vesalio, Nashville, TN, USA), $I V$ tPA intravenous tissue plasminogen activator
Pujol comprehensive stroke center. The MIVI $\mathrm{Q}^{\mathrm{TM}}$ aspiration catheter was the first-line treatment in 74 patients with large-vessel occlusion. Of these, 22 were excluded from the analyses (13 had posterior circulation occlusions, 4 had tandem occlusions in the cervical internal carotid and MCA, and 5 had anterior circulation stroke but were treated with first-line contact aspiration only). Thus, 52 patients were analyzed. A flowchart of patient selection is provided in Supplemental Fig. 2. Table 1 summarizes the demographic, clinical, and procedure characteristics of our cohort.

The $\mathrm{Q}^{\mathrm{TM}}$ aspiration catheter reached the occlusion in all patients, achieving FPE in 48\%. Final reperfusion was excellent $(\mathrm{mTICI} \geq 2 \mathrm{c})$ in $67.3 \%$ and successful (mTICI $\geq 2 \mathrm{~b})$ in $90.4 \%$. No device-related adverse events occurred, and no patients required rescue therapy. Table 2 reports procedural variables.

Table 3 reports the clinical outcomes related to safety and efficacy. In one patient with an M1 occlusion, an embolus that had migrated into the A2 segment of the anterior cerebral artery (unaffected territory) during withdrawal was retrieved uneventfully with the same system. A patient in his 40s (admission ASPECTS 5) treated with intravenous thrombolysis who achieved mTICI $2 \mathrm{~b}$ after 5 passes developed sICH and died. In another patient, microwire vessel perforation during microcatheter advancement (unrelated to the aspiration catheter or the stent retriever) resulted in a parenchymal hematoma (PH1), identified at 24h followup, but did not cause any neurological deterioration. Petechial reperfusion hemorrhages (HI1) or minor subarachnoid hemorrhage occurred in 8 patients.

Early neurological deterioration developed in 7 (13.5\%) patients. A total of 9 (17.3\%) patients died before hospital discharge, 2 from malignant edema related to large-volume stroke. At 90 days 24 (46.2\%) patients were functionally independent (mRS 0-2).

\section{Discussion}

Speed and grade of recanalization are of paramount importance in neurothrombectomy; therefore, choosing a safe and time-efficient strategy is key in stroke treatment.

Final reperfusion rates and functional outcomes after thromboaspiration and stent-retriever thrombectomy are similar [18]. Used as a stand-alone first-line technique, stent retrievers achieve better reperfusion with less need for rescue devices but require longer groin-to-reperfusion times [18]. Recently introduced approaches combining stent retrievers and large-bore aspiration catheters trap the thrombus between the catheter tip and the stent retriever while maintaining local aspiration [19, 20], a change from earlier combined approaches (e.g., Solumbra) where the stent retriever was retracted into the aspiration catheter [21]. 
Table 2 Angiographic outcomes

\begin{tabular}{|c|c|}
\hline Reperfusion and time-metrics & Results \\
\hline $\begin{array}{l}\text { Groin-puncture-to-revascularization (min), me- } \\
\text { dian }(I Q R)\end{array}$ & $42(22-66)$ \\
\hline $\begin{array}{l}\text { Time from first angiogram to recanalization (min), } \\
\text { median (IQR) }\end{array}$ & $28(15-59)$ \\
\hline \multicolumn{2}{|l|}{$Q^{T M} t F P E$} \\
\hline mTICI $3, n(\%)$ & $22(42.3)$ \\
\hline $\begin{array}{l}\text { Groin-puncture-to-revascularization (min), } \\
\text { median (IQR) }\end{array}$ & $29(20-45)$ \\
\hline $\begin{array}{l}\text { Time from first angiogram to recanalization } \\
\text { (min), median (IQR) }\end{array}$ & $15(11-26)$ \\
\hline \multicolumn{2}{|l|}{$Q^{T M} F P E$} \\
\hline mTICI $2 \mathrm{c}-3, n(\%)$ & $25(48)$ \\
\hline $\begin{array}{l}\text { Groin-puncture-to-revascularization (min), } \\
\text { median (IQR) }\end{array}$ & $26(20-39)$ \\
\hline $\begin{array}{l}\text { Time from first angiogram to recanalization } \\
\text { (min), median (IQR) }\end{array}$ & $15(11-24)$ \\
\hline \multicolumn{2}{|l|}{$Q^{T M} m T I C I \geq 2 b$ with a single pass } \\
\hline mTICI $\geq 2 \mathrm{~b}$ with a single pass, $n(\%)$ & $28(53.8)$ \\
\hline $\begin{array}{l}\text { Groin-puncture-to-revascularization (min), } \\
\text { median (IQR) }\end{array}$ & $26(20-41)$ \\
\hline $\begin{array}{l}\text { Time from first angiogram to recanalization } \\
\text { (min), median (IQR) }\end{array}$ & $15(11-26)$ \\
\hline \multicolumn{2}{|l|}{$\leq 2 Q^{T M}$ passes } \\
\hline $\mathrm{mTICI} \geq 2 \mathrm{~b}, n(\%)$ & $34(65.4)$ \\
\hline mTICI $2 \mathrm{c}-3, n(\%)$ & $29(55.7)$ \\
\hline Total passes, $n$ (mean) & $40(1.18)$ \\
\hline $\begin{array}{l}\text { Groin-puncture-to-revascularization (min), } \\
\text { median (IQR) }\end{array}$ & $26(20-46)$ \\
\hline $\begin{array}{l}\text { Time from first angiogram to recanalization } \\
\text { (min), median (IQR) }\end{array}$ & $15(11-34)$ \\
\hline \multicolumn{2}{|l|}{$\leq 3 Q^{T M}$ passes } \\
\hline $\mathrm{mTICI} \geq 2 \mathrm{~b}, n(\%)$ & $39(75)$ \\
\hline mTICI $2 \mathrm{c}-3, n(\%)$ & $32(61.5)$ \\
\hline Total passes, $n$ (mean) & $55(1.41)$ \\
\hline $\begin{array}{l}\text { Groin-puncture-to-revascularization (min), } \\
\text { median (IQR) }\end{array}$ & $32(20-55)$ \\
\hline $\begin{array}{l}\text { Time from first angiogram to recanalization } \\
\text { (min), median (IQR) }\end{array}$ & $18(14-40)$ \\
\hline \multicolumn{2}{|l|}{ Final Reperfusion } \\
\hline mTICI $3, n(\%)$ & $28(53.8)$ \\
\hline $\mathrm{mTICI} \geq 2 \mathrm{~b}, n(\%)$ & $47(90.4)$ \\
\hline mTICI $2 \mathrm{c}-3, n(\%)$ & $35(67.3)$ \\
\hline Total passes, mean & 2.46 \\
\hline
\end{tabular}

$I Q R$ interquartile range, $m T I C I$ modified thrombolysis in cerebral ischemia, $t F P E$ mTICI $=3$ after a single pass, FPE $\mathrm{mTICI} \geq 2 \mathrm{c}$ after a single pass

Combined approaches have shown improved reperfusion rates and FPE [22]; however, there remains considerable room for improvement in achieving an early and complete reperfusion [23].

Successful thromboaspiration requires using the largest catheter that the vessel can accommodate [24-26]. The
Table 3 Clinical efficacy and safety outcomes

\begin{tabular}{|c|c|}
\hline Efficacy and safety & Results \\
\hline 24-hour NIHSS, mean (IQR) & $13(4-18)$ \\
\hline Early neurological improvement, $n(\%)^{\mathrm{a}}$ & $28(53.8)$ \\
\hline NIHSS at discharge, mean (IQR) & $5(1-11)$ \\
\hline \multicolumn{2}{|l|}{$m R S$ at discharge, $n(\%)$} \\
\hline $0-1$ & $8(15.4)$ \\
\hline $0-2$ & $15(28.8)$ \\
\hline 3 & $8(15.4)$ \\
\hline 4 & $13(25)$ \\
\hline 5 & $7(13.5)$ \\
\hline 6 & $9(17.3)$ \\
\hline \multicolumn{2}{|l|}{ mRS at 90 days, $n(\%)$} \\
\hline $0-1$ & $20(38.5)$ \\
\hline $0-2$ & $24(46.2)$ \\
\hline 3 & $4(7.7)$ \\
\hline 4 & $6(11.5)$ \\
\hline 5 & $3(5.8)$ \\
\hline 6 & $15(28.8)$ \\
\hline \multicolumn{2}{|l|}{ Intracranial hemorrhage, $n(\%)$} \\
\hline $\mathrm{sICH}$ & $1(1.9)$ \\
\hline All ICH & $10(19.2)$ \\
\hline Early neurological deterioration, $n(\%)$ & $7(13.5)$ \\
\hline All-cause mortality at 90 days, $n(\%)$ & $15(28.8)$ \\
\hline In hospital mortality, $n(\%)$ & $9(17.3)$ \\
\hline Serious device-related adverse events, $n(\%)$ & $0(0)$ \\
\hline $\begin{array}{l}\text { Serious procedure related adverse events, } n \\
(\%)^{\mathrm{b}}\end{array}$ & $1(1.9)$ \\
\hline
\end{tabular}

NIHSS National Institute of Health Stroke Scale score, IQR interquartile range, $m R S$ modified Rankin Scale score, sICH symptomatic intracranial hemorrhage, $\mathrm{ICH}$ intracranial hemorrhage

a Early neurological improvement was defined as a reduction of $\geq 5$ points on the NIHSS or an NIHSS score $<4$ at 24-hours

${ }^{\mathrm{b}}$ Microwire perforation with contrast extravasation on angiography

MIVI $\mathrm{Q}^{\mathrm{TM}}$ aspiration catheter is designed to maximize lumen size, increasing flow rates and tip suction force [11]. Both properties combined have been shown to be necessary to effectively extract the clot, but in vitro experiments indicated that suction force is more relevant than aspiration flow in terms of efficacy, particularly in hard clots [27]. The MIVI $\mathrm{Q}^{\mathrm{TM}}$ exhibits these two physical properties, and especially the aspiration flow rate benefits from a dynamic effect as in vitro testing has demonstrated that it increases as the $\mathrm{Q}^{\mathrm{TM}}$ is retracted inside the guiding catheter [11]. It can be used alone or combined with a stent retriever, as in our cohort. In this preliminary clinical experience, there were no device-related adverse events, and the angiographic, time-metric, and clinical outcomes were similar to those in other studies using combined mechanical thrombectomy approaches [20, 28-30].

Delivering large-bore aspiration catheters intracranially to the thrombus is not always easy [31] because of vessel 
tortuosity, underlying intracranial atherosclerosis, or even the anatomical position where the ophthalmic artery originates from the carotid siphon [32]. The soft and flexible design of the MIVI $\mathrm{Q}^{\mathrm{TM}}$ aspiration catheter resulted in excellent trackability; in all patients, the catheter was navigated to the occlusion uneventfully. These results compare favorably with those reported in an initial experience with the Sofia catheter (MicroVention, Tustin, CA, USA), where the occlusion was reached uneventfully in $96 \%$ of cases [33]. The $\mathrm{Q}^{\mathrm{TM}}$ catheter was coaxially advanced over the $\operatorname{Rebar}^{\mathrm{TM}} 18$ microcatheter, and no stent anchoring [34] or "blind exchange" maneuvers [35] were needed to navigate the $\mathrm{Q}^{\mathrm{TM}}$ catheter, even when using larger caliber catheters and when the arterial anatomy was tortuous. Avoiding anchoring and exchange maneuver eliminates a theoretical risk of vascular injury.

The $\mathrm{Q}^{\mathrm{TM}}$ catheter design takes advantage of fluid mechanics theory so that the suction force in the tip of the $\mathrm{Q}^{\mathrm{TM}}$ catheter increases when it is retrieved inside the guiding catheter, potentially diminishing the risk of distal emboli migrating during system retrieval [11]. This may explain the low rate of complications related to emboli migrating to previously unaffected territories $(1.9 \%)$ in our series.

Another potential advantage of the MIVI Q ${ }^{\mathrm{TM}}$ aspiration catheter design is that it does not require a rotating hemostatic valve connected to a saline flush line, thus enabling faster preprocedural preparation and faster purging after its retrieval when additional passes are necessary and thereby improving the efficiency of interventions.

Our successful reperfusion rate $(90.4 \%)$ is in line with those reported by Hesse et al. [30] in the primary combined approach (PCA) group (86\%), CAPTIVE (100\%) [20], and SAVE (95\%) [28]. Likewise, our rate of final TICI $3(53.8 \%)$ is in line with those reported in PCA $(37.5 \%)$, CAPTIVE (33\%), and SAVE (56\%). The proportion of procedures that achieved $\mathrm{mTICI} \geq 2 \mathrm{~b}$ with a single pass $(53.8 \%)$ is in line with rates reported in CAPTIVE $(59 \%)$ and SAVE $(74 \%)$. Our rate of tFPE $(42.3 \%)$ is similar to that reported in SAVE (45\%), but higher than that reported by Hesse et al. [30] (26\%), who used the Solumbra technique [21] for most cases in the PCA group.

Median groin-to-recanalization time was $42 \mathrm{~min}$, similar to that reported in SAVE (34 min) [28] and PCA (51 min) [30], but longer than in CAPTIVE (14 min) [20].

Lastly, $46.2 \%$ of patients in our cohort had good clinical outcomes $(\mathrm{mRS} \leq 2)$ at 90 -days, comparable to the $49 \%$ reported in CAPTIVE [20].

In summary, the procedure times and proportion of patients achieving FPE, tFPE, excellent and successful final reperfusion and good clinical outcomes at 3 months, were in line with those reported in other cohorts where combined approaches were used.

\section{Limitations}

This retrospective, non-randomized study included relatively few patients at a single center with no control group, and reperfusion and clinical outcomes were local operatormeasured; thus, caution is essential in extrapolating the results. Nevertheless, our preliminary results include the learning curve inherent in using new devices and merit further studies with larger samples to determine the efficacy of this approach compared to other devices and approaches.

\section{Conclusion}

This preliminary study suggests that the MIVI $\mathrm{Q}^{\mathrm{TM}}$ aspiration catheter has a good efficacy and safety profile when used in combination with stent retrievers, achieving high reperfusion rates and favorable clinical outcomes.

Supplementary Information The online version of this article (https:// doi.org/10.1007/s00062-021-01065-7) contains supplementary material, which is available to authorized users.

Acknowledgements The authors thank Raquel Pujana and Ana Pujana for the graphic illustration.

Funding This research did not receive any specific grant from funding agencies in the public, commercial, or not-for-profit sectors.

Author Contribution S. Remollo: Conceptualization, methodology, formal analysis, resources, data curation, writing-original draft, writing - review and editing, visualization, supervision, project administration; M. Terceño: Resources, data curation, writing - review and editing; M. Werner: Resources, data curation, writing-review and editing; C. Castaño: Resources, data curation, writing - review and editing; M. Hernández-Pérez: Resources, data curation, writing-review and editing; J. Blasco: Writing — review and editing; L. San Román: Writing — review and editing; P. Daunis-i-Estadella: Formal analysis, writing-review and editing; S. Thió-Henestrosa: Formal analysis, writing-review and editing; V. Cuba: Writing—review and editing; A. Gimeno: Writing - review and editing; J. Puig: Formal analysis, writing — original draft, writing — review and editing, visualization, supervision.

\section{Declarations}

Conflict of interest S. Remollo, M. Terceño, M. Werner, C. Castaño, M. Hernández-Pérez, J. Blasco, L. San Román, P. Daunis-i-Estadella, S. Thió-Henestrosa, V. Cuba, A. Gimeno and J. Puig declare that they have no competing interests.

Ethical standards All procedures performed in studies involving human participants or on human tissue were in accordance with the ethical standards of the institutional (Ethics Committee of Hospital Universitari Germans Trias i Pujol) and/or national research committee and with the 1975 Helsinki declaration and its later amendments or comparable ethical standards. Informed consent was obtained from all individual participants included in the study.

Open Access This article is licensed under a Creative Commons Attribution 4.0 International License, which permits use, sharing, adapta- 
tion, distribution and reproduction in any medium or format, as long as you give appropriate credit to the original author(s) and the source, provide a link to the Creative Commons licence, and indicate if changes were made. The images or other third party material in this article are included in the article's Creative Commons licence, unless indicated otherwise in a credit line to the material. If material is not included in the article's Creative Commons licence and your intended use is not permitted by statutory regulation or exceeds the permitted use, you will need to obtain permission directly from the copyright holder. To view a copy of this licence, visit http://creativecommons.org/licenses/by/4. $0 \%$.

\section{References}

1. Berkhemer OA, Fransen PS, Beumer D, van den Berg LA, Lingsma HF, Yoo AJ, Schonewille WJ, Vos JA, Nederkoorn PJ, Wermer MJ, van Walderveen MA, Staals J, Hofmeijer J, van Oostayen JA, Lycklama à Nijeholt GJ, Boiten J, Brouwer PA, Emmer BJ, de Bruijn SF, van Dijk LC, Kappelle LJ, Lo RH, van Dijk EJ, de Vries J, de Kort PL, van Rooij WJ, van den Berg JS, van Hasselt BA, Aerden LA, Dallinga RJ, Visser MC, Bot JC, Vroomen PC, Eshghi O, Schreuder TH, Heijboer RJ, Keizer K, Tielbeek AV, den Hertog HM, Gerrits DG, van den Berg-Vos RM, Karas GB, Steyerberg EW, Flach HZ, Marquering HA, Sprengers ME, Jenniskens SF, Beenen LF, van den Berg R, Koudstaal PJ, van Zwam WH, Roos YB, van der Lugt A, van Oostenbrugge RJ, Majoie CB, Dippel DW; MR CLEAN Investigators. A randomized trial of intraarterial treatment for acute ischemic stroke. N Engl J Med. 2015;372:11-20. Erratum in: N Engl J Med. 2015;372:394.

2. Jovin TG, Chamorro A, Cobo E, de Miquel MA, Molina CA, Rovira A, San Román L, Serena J, Abilleira S, Ribó M, Millán M, Urra X, Cardona P, López-Cancio E, Tomasello A, Castaño C, Blasco J, Aja L, Dorado L, Quesada H, Rubiera M, HernandezPérez M, Goyal M, Demchuk AM, von Kummer R, Gallofré M, Dávalos A; REVASCAT Trial Investigators. Thrombectomy within 8 hours after symptom onset in ischemic stroke. N Engl J Med. 2015;372:2296-306

3. Saver JL, Goyal M, Bonafe A, Diener HC, Levy EI, Pereira VM, Albers GW, Cognard C, Cohen DJ, Hacke W, Jansen O, Jovin TG, Mattle HP, Nogueira RG, Siddiqui AH, Yavagal DR, Baxter BW, Devlin TG, Lopes DK, Reddy VK, du Mesnil de Rochemont R, Singer OC, Jahan R; SWIFT PRIME Investigators. Stent-retriever thrombectomy after intravenous t-PA vs. t-PA alone in stroke. $\mathrm{N}$ Engl J Med. 2015;372:2285-95.

4. Goyal M, Demchuk AM, Menon BK, Eesa M, Rempel JL, Thornton J, Roy D, Jovin TG, Willinsky RA, Sapkota BL, Dowlatshahi D, Frei DF, Kamal NR, Montanera WJ, Poppe AY, Ryckborst KJ, Silver FL, Shuaib A, Tampieri D, Williams D, Bang OY, Baxter BW, Burns PA, Choe H, Heo JH, Holmstedt CA, Jankowitz B, Kelly M, Linares G, Mandzia JL, Shankar J, Sohn SI, Swartz RH, Barber PA, Coutts SB, Smith EE, Morrish WF, Weill A, Subramaniam S, Mitha AP, Wong JH, Lowerison MW, Sajobi TT, Hill MD; ESCAPE Trial Investigators. Randomized assessment of rapid endovascular treatment of ischemic stroke. N Engl J Med. 2015;372:1019-30.

5. Campbell BC, Mitchell PJ, Kleinig TJ, Dewey HM, Churilov L, Yassi N, Yan B, Dowling RJ, Parsons MW, Oxley TJ, Wu TY, Brooks M, Simpson MA, Miteff F, Levi CR, Krause M, Harrington TJ, Faulder KC, Steinfort BS, Priglinger M, Ang T, Scroop R, Barber PA, McGuinness B, Wijeratne T, Phan TG, Chong W, Chandra RV, Bladin CF, Badve M, Rice H, de Villiers L, Ma H, Desmond PM, Donnan GA, Davis SM; EXTEND-IA Investigators. Endovascular therapy for ischemic stroke with perfusion-imaging selection. N Engl J Med. 2015;372:1009-18.

6. Linfante I, Starosciak AK, Walker GR, Dabus G, Castonguay AC, Gupta R, Sun CH, Martin C, Holloway WE, Mueller-Kronast N,
English JD, Malisch TW, Marden FA, Bozorgchami H, Xavier A, Rai AT, Froehler MT, Badruddin A, Nguyen TN, Taqi MA, Abraham MG, Janardhan V, Shaltoni H, Novakovic R, Yoo AJ, AbouChebl A, Chen PR, Britz GW, Kaushal R, Nanda A, Issa MA, Nogueira RG, Zaidat OO. Predictors of poor outcome despite recanalization: a multiple regression analysis of the NASA registry. J Neurointerv Surg. 2016;8:224-9.

7. Kharouba R, Gavriliuc P, Yaghmour NE, Gomori JM, Cohen JE, Leker RR. Number of stentriever passes and outcome after thrombectomy in stroke. J Neuroradiol. 2019;46:327-30.

8. Zaidat OO, Castonguay AC, Linfante I, Gupta R, Martin CO, Holloway WE, Mueller-Kronast N, English JD, Dabus G, Malisch TW, Marden FA, Bozorgchami H, Xavier A, Rai AT, Froehler MT, Badruddin A, Nguyen TN, Taqi MA, Abraham MG, Yoo AJ, Janardhan V, Shaltoni H, Novakovic R, Abou-Chebl A, Chen PR, Britz GW, Sun CJ, Bansal V, Kaushal R, Nanda A, Nogueira RG. First Pass Effect: A New Measure for Stroke Thrombectomy Devices. Stroke. 2018;49:660-6.

9. Froehler MT. Comparison of Vacuum Pressures and Forces Generated by Different Catheters and Pumps for Aspiration Thrombectomy in Acute Ischemic Stroke. Interv Neurol. 2017;6:199-206.

10. Yaeger K, Iserson A, Singh P, Wolf J, Vidal E, Oxley T, Costa AB, Fifi JT. A technical comparison of thrombectomy vacuum aspiration systems. J Neurointerv Surg. 2020;12:72-6.

11. Long TD, Kallmes DF, Hanel R, Shigematsu T, Halaszyn AM, Wolter J, Berenstein A. Novel aspiration catheter design for acute stroke thrombectomy. J Neurointerv Surg. 2019;11:190-5.

12. Adams HP Jr, del Zoppo G, Alberts MJ, Bhatt DL, Brass L, Furlan A, Grubb RL, Higashida RT, Jauch EC, Kidwell C, Lyden PD, Morgenstern LB, Qureshi AI, Rosenwasser RH, Scott PA, Wijdicks EF; American Heart Association; American Stroke Association Stroke Council; Clinical Cardiology Council; Cardiovascular Radiology and Intervention Council; Atherosclerotic Peripheral Vascular Disease and Quality of Care Outcomes in Research Interdisciplinary Working Groups. Guidelines for the early management of adults with ischemic stroke: a guideline from the American Heart Association/American Stroke Association Stroke Council, Clinical Cardiology Council, Cardiovascular Radiology and Intervention Council, and the Atherosclerotic Peripheral Vascular Disease and Quality of Care Outcomes in Research Interdisciplinary Working Groups: the American Academy of Neurology affirms the value of this guideline as an educational tool for neurologists. Stroke. 2007;38:1655-711.

13. Hacke W, Kaste M, Fieschi C, von Kummer R, Davalos A, Meier D, Larrue V, Bluhmki E, Davis S, Donnan G, Schneider D, DiezTejedor E, Trouillas P. Randomised double-blind placebo-controlled trial of thrombolytic therapy with intravenous alteplase in acute ischaemic stroke (ECASS II). Second European-Australasian Acute Stroke Study Investigators. Lancet. 1998;352:1245-51.

14. Dargazanli C, Fahed R, Blanc R, Gory B, Labreuche J, Duhamel A, Marnat G, Saleme S, Costalat V, Bracard S, Desal H, Mazighi M, Consoli A, Piotin M, Lapergue B; ASTER Trial Investigators. Modified Thrombolysis in Cerebral Infarction 2C/Thrombolysis in Cerebral Infarction 3 Reperfusion Should Be the Aim of Mechanical Thrombectomy: Insights From the ASTER Trial (Contact Aspiration Versus Stent Retriever for Successful Revascularization). Stroke. 2018;49:1189-96.

15. Almekhlafi MA, Mishra S, Desai JA, Nambiar V, Volny O, Goel A, Eesa M, Demchuk AM, Menon BK, Goyal M. Not all "successful" angiographic reperfusion patients are an equal validation of a modified TICI scoring system. Interv Neuroradiol. 2014;20:21-7.

16. Haussen DC, Rebello LC, Nogueira RG. Optimizating Clot Retrieval in Acute Stroke: The Push and Fluff Technique for ClosedCell Stentrievers. Stroke. 2015;46:2838-42.

17. Nikoubashman O, Alt JP, Nikoubashman A, Büsen M, Heringer S, Brockmann C, Brockmann MA, Müller M, Reich A, Wiesmann M. Optimizing endovascular stroke treatment: removing the micro- 
catheter before clot retrieval with stent-retrievers increases aspiration flow. J Neurointerv Surg. 2017;9:459-62. Erratum in: J Neurointerv Surg. 2018;10:e10.

18. Tsang COA, Cheung IHW, Lau KK, Brinjikji W, Kallmes DF, Krings T. Outcomes of Stent Retriever versus Aspiration-First Thrombectomy in Ischemic Stroke: A Systematic Review and Meta-Analysis. AJNR Am J Neuroradiol. 2018;39:2070-6.

19. Maus V, Behme D, Kabbasch C, Borggrefe J, Tsogkas I, Nikoubashman O, Wiesmann M, Knauth M, Mpotsaris A, Psychogios MN. Maximizing First-Pass Complete Reperfusion with SAVE. Clin Neuroradiol. 2018;28:327-38.

20. McTaggart RA, Tung EL, Yaghi S, Cutting SM, Hemendinger M, Gale HI, Baird GL, Haas RA, Jayaraman MV. Continuous aspiration prior to intracranial vascular embolectomy (CAPTIVE): a technique which improves outcomes. J Neurointerv Surg. 2017;9:1154-9.

21. Delgado Almandoz JE, Kayan Y, Young ML, Fease JL, Scholz JM, Milner AM, Hehr TH, Roohani P, Mulder M, Tarrel RM. Comparison of clinical outcomes in patients with acute ischemic strokes treated with mechanical thrombectomy using either Solumbra or ADAPT techniques. J Neurointerv Surg. 2016;8:1123-8.

22. Ospel JM, McTaggart R, Kashani N, Psychogios M, Almekhlafi M, Goyal M. Evolution of Stroke Thrombectomy Techniques to Optimize First-Pass Complete Reperfusion. Semin Intervent Radiol. 2020;37:119-31.

23. Goyal M, Menon BK, van Zwam WH, Dippel DW, Mitchell PJ, Demchuk AM, Dávalos A, Majoie CB, van der Lugt A, de Miquel MA, Donnan GA, Roos YB, Bonafe A, Jahan R, Diener HC, van den Berg LA, Levy EI, Berkhemer OA, Pereira VM, Rempel J, Millán M, Davis SM, Roy D, Thornton J, Román LS, Ribó M, Beumer D, Stouch B, Brown S, Campbell BC, van Oostenbrugge RJ, Saver JL, Hill MD, Jovin TG; HERMES collaborators. Endovascular thrombectomy after large-vessel ischaemic stroke: a meta-analysis of individual patient data from five randomised trials. Lancet. 2016;387:1723-31.

24. Lapergue B, Blanc R, Guedin P, Decroix JP, Labreuche J, Preda C, Bartolini B, Coskun O, Redjem H, Mazighi M, Bourdain F, Rodesch G, Piotin M. A Direct Aspiration, First Pass Technique (ADAPT) versus Stent Retrievers for Acute Stroke Therapy: An Observational Comparative Study. AJNR Am J Neuroradiol. 2016;37:1860-5.

25. Romano DG, Cioni S, Vinci SL, Pero G, Comelli C, Comai A, Peschillo S, Mardighian D, Castellan L, Resta F, Piano MG, Comelli S, Barletta L, Puliti A, Leonini S, Bracco S. Thromboaspiration technique as first approach for endovascular treatment of acute ischemic stroke: initial experience at nine Italian stroke centers. J Neurointerv Surg. 2017;9:6-10.
26. Lapergue B, Blanc R, Gory B, Labreuche J, Duhamel A, Marnat G, Saleme S, Costalat V, Bracard S, Desal H, Mazighi M, Consoli A, Piotin M; ASTER Trial Investigators. Effect of Endovascular Contact Aspiration vs Stent Retriever on Revascularization in Patients With Acute Ischemic Stroke and Large Vessel Occlusion: The ASTER Randomized Clinical Trial. JAMA. 2017;318:443-52.

27. Fernandez-Sanchez D, Garcia-Sabido D, Jovin TG, Villanova H, Andersson T, Nogueira RG, Cognard C, Ribo M, Siddiqui AH, Galve I, Arad O, Salmon F. Suction force rather than aspiration flow correlates with recanalization in hard clots: an in vitro study model. J Neurointerv Surg. 2021; doi: 10.1136/neurintsurg-2020-017242. Epub ahead of print.

28. Maus V, Henkel S, Riabikin A, Riedel C, Behme D, Tsogkas I, Hesse AC, Abdullayev N, Jansen O, Wiesmann M, Mpotsaris A, Psychogios MN. The SAVE Technique : Large-Scale Experience for Treatment of Intracranial Large Vessel Occlusions. Clin Neuroradiol. 2019;29:669-76.

29. Brehm A, Maus V, Tsogkas I, Colla R, Hesse AC, Gera RG, Psychogios MN. Stent-retriever assisted vacuum-locked extraction (SAVE) versus a direct aspiration first pass technique (ADAPT) for acute stroke: data from the real-world. BMC Neurol. 2019;19:65.

30. Hesse AC, Behme D, Kemmling A, Zapf A, Große Hokamp N, Frischmuth I, Maier I, Liman J, Tsogkas I, Buhk JH, Tran J, Fiehler J, Mpotsaris A, Schramm P, Berlis A, Knauth M, Psychogios MN. Comparing different thrombectomy techniques in five large-volume centers: a 'real world' observational study. J Neurointerv Surg. 2018;10:525-9.

31. Spiotta AM, Chaudry MI, Hui FK, Turner RD, Kellogg RT, Turk AS. Evolution of thrombectomy approaches and devices for acute stroke: a technical review. J Neurointerv Surg. 2015;7:2-7.

32. Kang DH, Hwang YH. Frontline Contact Aspiration Treatment for Emergent Large Vessel Occlusion: A Review Focused on Practical Techniques. J Stroke. 2019;21:10-22.

33. Stampfl S, Kabbasch C, Müller M, Mpotsaris A, Brockmann M, Liebig T, Wiesmann M, Bendszus M, Möhlenbruch MA. Initial experience with a new distal intermediate and aspiration catheter in the treatment of acute ischemic stroke: clinical safety and efficacy. J Neurointerv Surg. 2016;8:714-8.

34. Singh J, Wolfe SQ, Janjua RM, Hedayat H, Burnette C. Anchor technique: Use of stent retrievers as an anchor to advance thrombectomy catheters in internal carotid artery occlusions. Interv Neuroradiol. 2015;21:707-9.

35. Haussen DC, Al-Bayati AR, Eby B, Ravindran K, Rodrigues GM, Frankel MR, Nogueira RG. Blind exchange with mini-pinning technique for distal occlusion thrombectomy. J Neurointerv Surg. 2020;12:392-5. 